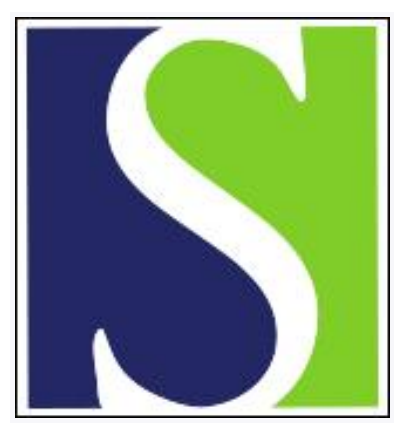

Scand J Work Environ Health 1985;11(5):371-379

https://doi.org/10.5271/sjweh.2210

Issue date: Oct 1985

Urinary elimination of styrene in experimental and occupational exposure.

by Pezzagno G, Ghittori S, Imbriani M, Capodaglio E

This article in PubMed: www.ncbi.nlm.nih.gov/pubmed/4071003

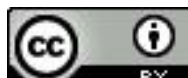




\title{
Urinary elimination of styrene in experimental and occupational exposure
}

\author{
by Giulio Pezzagno, MD, ${ }^{1}$ Sergio Ghittori, BS, ${ }^{2}$ Marcello Imbriani, MD, ${ }^{1}$ Emanuele Capodaglio, MD ${ }^{1}$
}

\begin{abstract}
PEZZAGNO G, GHITTORI S, IMBRIANI M, CAPODAGLIO E. Urinary elimination of styrene in experimental and occupational exposure. Scand J Work Environ Health 11 (1985) 371-379. Twenty human volunteers were exposed to styrene vapor at $273-1654 \mu \mathrm{mol} / \mathrm{m}^{3}\left(28.4-172.3 \mathrm{mg} / \mathrm{m}^{3}\right)$ for a period of 1 to $3 \mathrm{~h}$ at rest ( 15 cases) and during light physical exercise ( 5 cases). Subsequently 51 workers occupationally exposed to styrene were studied during a workweek (median value $1138 \mu \mathrm{mol} / \mathrm{m}^{3}$, geometric standard deviation 2.23). As expected, the relative uptake averaged about $65 \%$, and the ratio of the alveolar concentration to the time-weighted average of the environmental concentration averaged about 0.15 . Both in the experimentally exposed subjects and in the occupationally exposed workers the urinary styrene concentration showed a linear relationship to the corresponding environmental time-weighted average concentration. The correlation coefficients of the regression lines ranged between 0.88 (occupationally exposed group) and more than 0.93 (experimentally exposed groups). The regression coefficients were closely linked to the amount of styrene taken up and to the exposure times. The findings show that the urinary styrene concentration can be used as an appropriate biological exposure indicator whose meaning differs from that of other suggested indices. As an example, in occupationally exposed subjects performing moderate work the urinary styrene concentration corresponding to the time-weighted average of the threshold limit value is $815 \mathrm{nmol} / \mathrm{l}$, and the $95 \%$ lower confidence limit (biological threshold) is $740 \mathrm{nmol} / 1$.
\end{abstract}

Key terms: biological monitoring, styrene, urinalysis.

In industry styrene is a widely used solvent which can cause several toxic effects (28). It is a volatile compound entering the body mainly through the lungs or skin $(8,31)$. General studies have been devoted to its uptake $(1,37)$, distribution in body tissues $(6,10)$, and elimination as urinary metabolites (mandelic and phenylglyoxylic acids) $(11,12,21,28)$. It is a substance easily soluble in the blood and biological tissues and therefore probably accumulates with each consecutive exposure $(9,10)$.

For biological monitoring, determination can be made of the concentration of the parent $(1,5,36)$ or metabolized compounds $(1,11,28)$ in alveolar or expired air samples, in venous or arterial capillary blood samples, and in urine samples. Determination of its uptake during exposure has also been proposed as an exposure indicator (13).

More than $90 \%$ of the styrene taken up in the organism is excreted in urine as metabolites (28). Elimination via the lungs is less than $3 \%(6,10,13)$. Small amounts of styrene are eliminated as such by means of biological fluids (urine, sweat) (7).

In previous studies carried out during experimental and occupational exposure to certain solvents, the

\footnotetext{
1 Second Section of Occupational Health, Department of Preventive, Occupational and Community Medicine, University of Pavia.

2 "Clinica del Lavoro"' Foundation, Medical Center of Pavia, Italy.
}

Reprint requests to: Dr G Pezzagno, II Sezione di Medicina del Lavoro, Via S Boezio 24, I-27100 Pavia, Itąly. relationship between the time-weighted environmental concentration and the urinary concentration of solvents as such (nonmetabolized amount) has been studied. The results suggest that the concentration of the solvent in a sample of urine (produced during the exposure period) could be considered an appropriate indicator of exposure from which the biological indices corresponding to the time-weighted average (TWA) of the threshold limit value (TLV) could be derived $(17,23,29)$.

The main aim of our study was to verify the relationship between the urinary styrene concentration produced during a period of controlled exposure and the corresponding mean environmental concentration in the breathing zone.

\section{Subjects}

Experiments were performed in a laboratory on healthy volunteer subjects (stage 1) and directly on the work premises on groups of subjects occupationally exposed (stage 2).

\section{Stage 1}

Twenty subjects, 14 males and 6 females (23 to 51 years of age), were exposed, in an open exposure chamber (16), to styrene at different concentrations but constant for each subject under study. The total group was divided into four five-subject subgroups. For each subgroup different exposure means were chosen as fol- 

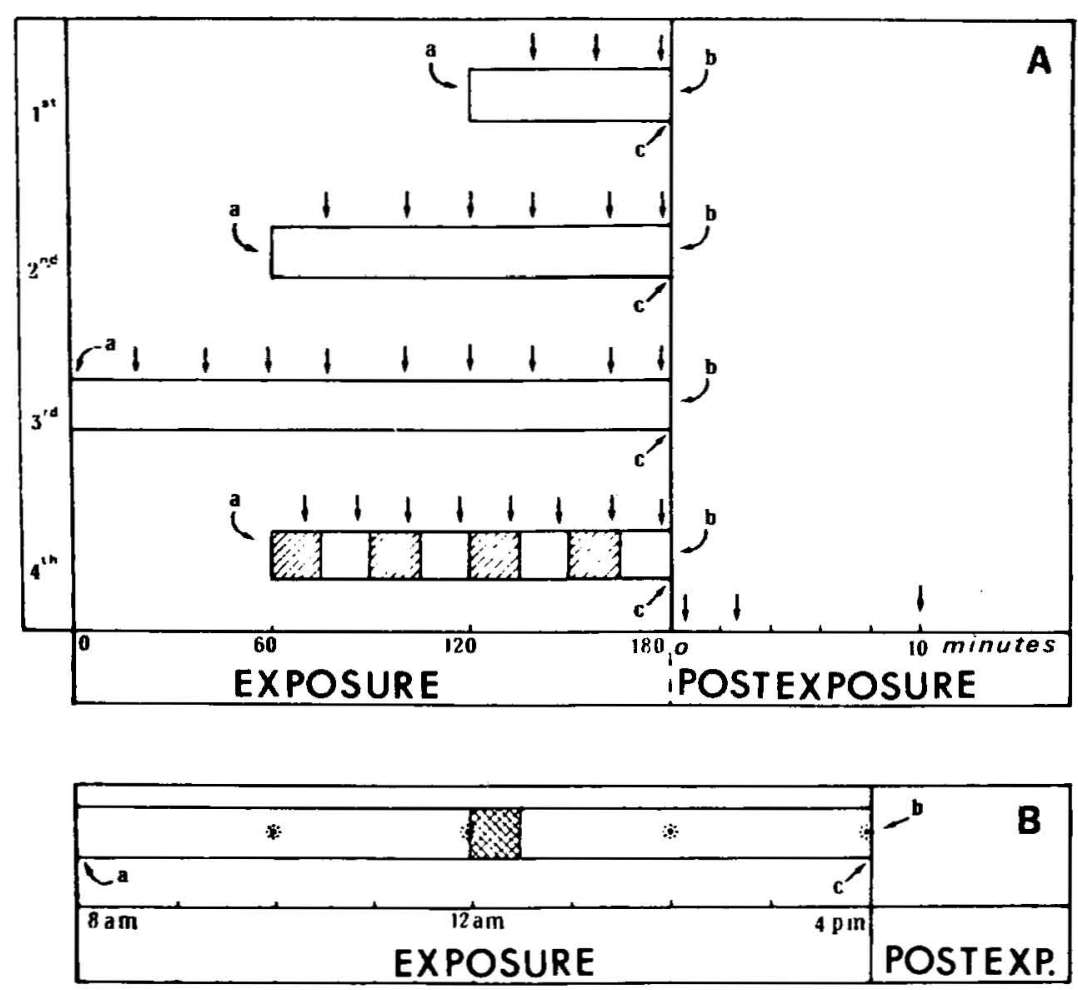

Figure 1. Scheme applied during the experimental chamber exposure (stage 1) (A) and during occupational exposure (stage 2) (B) to styrene; $1^{\text {st }}, 2^{\text {nd }}$, $3^{\text {rd }}$ and $4^{\text {th }}$ refer to the four subgroups considered. (See the text.) The arrows indicate the collecting times of environmental, alveolar, mixed-expired air, and pulmonary ventilation measurements (arrows in the postexposure period refer to collecting times of alveolar samples only); asterisks refer to collecting time of personal samples (stage 2, B); a = bladder emptying, immediately before exposure; $b=$ urine sample collection; $c=$ venous sample collection; and dotted areas $=$ periods of physical exercise (in A), and lunch break (in B). lows: subgroup 1: 1-h exposure at rest, subgroup 2: 2-h exposure at rest, subgroup 3: 3-h exposure at rest, and subgroup 4: exposure during light physical exercise and alternately at rest (15-min work load of 50 $\mathrm{W}$ on a bycicle ergometer, $15 \mathrm{~min}$ at rest, four times each during $2 \mathrm{~h}$ of exposure) (figure $1 \mathrm{~A}$ ).

The subjects went into the exposure chamber immediately after emptying their bladder. At the end of the: chosen exposure period a urine sample was collected (for the precautions taken, see the Methods section) from which to measure the styrene concentration $\left(\mathrm{C}_{\mathrm{u}}\right)$.

Samples of chamber air, alveolar air, and mixedexpired air (the last sample being taken from the subjects of the first three subgroups only) were collected at regular intervals of $20 \mathrm{~min}$. Pulmonary ventilation was measured simultaneously with the expired air sampling. Finally, immediately after the exposure, a venous blood sample was taken (from a brachial vein).

For all the subjects of the four subgroups, the sampling of alveolar air continued for $10 \mathrm{~min}$ after the end of the exposure (at 30 and $150 \mathrm{~s}$ and then at 10 min) (figure $1 \mathrm{~A}$ ).

\section{Stage 2}

The second stage of the study involved 51 male subjects (average age of the group 44 years) employed at a plastic boat factory (first factory) and in a plastic button factory (second factory). Shifts were $8 \mathrm{~h}$ daily (0800-1600, with a half-hour lunch break). The oc- cupational exposure included, in addition to styrene, also acetone at a concentration of $2801 \mu \mathrm{mol} / \mathrm{m}^{3}$ (median value) (geometric standard deviation $=1.95$ ) (corresponding to $162.3 \mathrm{mg} / \mathrm{m}^{3}$ ).

Urine was collected from all the subjects at 0800 , 1200 , and 1600 . A total of 101 samples was taken (figure $1 \mathrm{~B}$ ). In addition, during the workday, the environmental concentration of styrene (breathing zone) was measured by means of personal passive samplers (25).

The complete exposure period was monitored for each subject with four consecutive dosimeters and from calculations of the time-weighted individual value $\left(\mathrm{C}_{\overline{\mathrm{I}}}\right)$ from the four determinations.

\section{Methods}

Urine collection and styrene urinary concentrations During stages 1 and 2 the urine was collected from all the subjects in the same manner in 120-ml glass vials (Supelco Vials) with airtight plugs (without silicone). The vials were equipped with a valve (Minimert valve Supelco) enabling a headspace gas sample of styrene to be withdrawn over the urine after partial pressure equilibration. The volume of urine was measured by weight, starting from the urine density.

The subjects voided rapidly in areas known to be unpolluted. (Significant variations in $C_{\bar{u}}$ do not occur if collection time is less than $1 \mathrm{~min}$.) The vials were then stored at $37^{\circ} \mathrm{C}$ for $2 \mathrm{~h}$ and shaken periodically 
to speed the separation and partial pressure equilibrium of the styrene vapor between the urine and the headspace air over it. After at least $1 \mathrm{~h}$ a headspace air sample was analyzed by means of a gas chromatograph (HP $5880 \mathrm{~A}$ ) plus a mass selective detector (HP 5970 A). The analytical conditions for the gas chromatograph were as follows: cross-linked column $5 \%$ phenyl methyl silicone (internal diameter $0.2 \mathrm{~mm}$, length 25 $\mathrm{m})$, column temperature $150^{\circ} \mathrm{C}$, carrier gas helium with a flow rate of $1 \mathrm{ml} / \mathrm{min}$, retention time of styrene 2 min $10 \mathrm{~s}$, sampler volume (kept at $37^{\circ} \mathrm{C}$ ) $0.5 \mathrm{ml}$. (The headspace air sample was transferred to the gas chromatograph sampler by means of a Hamilton gastight syringe.) The analytical conditions for the mass selective detector were: monitored ion 104, dwell time 50 $\mathrm{ms}$, selected-ion-monitoring window time 0.1 amount mass units, electromultipler voltage $1800 \mathrm{~V}$.

From the headspace styrene concentration it is easy to obtain the urinary concentration if the $\lambda$ urine/air value and the volume of the two phases [urine volume $\left(V_{u}\right)$ and headspace air volume $\left.\left(V_{a}\right)\right]$ are known. Once a balance between the two phases of the vial has been reached, the volume of dissolved solvent $(x)$ is divided between $V_{u}$ and $V_{a}$ proportionally to $\lambda$ (Ostwald partition coefficient) ( $\mathrm{x}_{1}$ and $\mathrm{x}_{2}$ are the two volumes of solvent distributed to $V_{u}$ and $V_{a}$, respectively): $\mathrm{x}=\mathrm{x}_{1}+\mathrm{x}_{2}$ and $\lambda=\left[\left(\mathrm{x}_{1} / \mathrm{V}_{\mathrm{u}}\right) /\left(\mathrm{x}_{2} / \mathrm{V}_{\mathrm{a}}\right)\right]$ (concentration ratio, by definition). Thus: $x=\lambda \cdot x_{2}$. $\left(\mathrm{V}_{\mathrm{u}} / \mathrm{V}_{\mathrm{a}}\right)+\mathrm{x}_{2}=\mathrm{x}_{2}\left[\lambda \cdot\left(\mathrm{V}_{\mathrm{u}} / \mathrm{V}_{\mathrm{a}}\right)+1\right]$, and $\left(\mathrm{x} / \mathrm{V}_{\mathrm{u}}\right)=$ $\left(\mathrm{x}_{2} / \mathrm{V}_{\mathrm{u}}\right) \cdot\left[\lambda \cdot\left(\mathrm{V}_{\mathrm{u}} / \mathrm{V}_{\mathrm{a}}\right)+1\right]$ (standard in air), where $\mathrm{x}_{2}$ is the measured amount of styrene in the headspace. The $\lambda$ urine/air of styrene, at $37^{\circ} \mathrm{C}$, is 7.13 (17).

\section{Determination of venous blood concentration}

Similar to what was described for the $\mathrm{C}_{\dot{\mathrm{u}}}$ measurement, in the experimental exposure only, the heparinated venous blood sample $(5 \mathrm{ml})$ was kept at $37^{\circ} \mathrm{C}$ in similar airtight vials (volume $13.5 \mathrm{ml}$ ) and shaken periodically for the determination of the venous blood concentration $\left(C_{\mathrm{v}}\right)$. The analysis of the headspace samples and the blood concentration determination followed the same modalities described with regard to the $\mathrm{C}_{\overline{\mathrm{u}}}$ determination. The $\lambda$ blood/air value used was 52 (32).

\section{Alveolar and mixed-expiratory air sampling for the styrene concentration}

In the experimental exposure only, the alveolar $\left(\mathrm{C}_{\mathrm{A}}\right)$ and mixed-expired $\left(C_{\overline{\mathrm{E}}}\right)$ air samples were collected every $20 \mathrm{~min}$ during the exposure at the same time as the collection of environmental air from the chamber and the pulmonary ventilation measurement (V). Three additional air samples were collected at the end of the exposure (after 30 and $150 \mathrm{~s}$ and after $10 \mathrm{~min}$ ).

The open-circuit apparatus is schematized in figure 2. It had a oneway valve (through which the subject under study breathed), the inspiratory end of which was equipped with a pulmonary ventilation analyzer (ultrasonic spirometer LS 75 Bourns), and the expiratory end of which had a fourway tap allowing the expiratory flow to pass across an alveolar sampler and an expiratory air sampling bag, a plastic bag whose inner wall is an aluminum foil barrier ( 51 of volume) which opens outside but is kept closed by means of a oneway valve letting the extra expired air out (Multilayer gas sampling bag, Calibrated Instruments). The bag was provided with a device to draw the air samples either into a gastight syringe to be analyzed or to the outside directly. The entire expiratory part of the circuit was placed in a metal container (kept at $37^{\circ} \mathrm{C}$ ).

The alveolar sampler was a metal cylindrical device in which an alveolar air sample can be trapped and from which the sample can be partly taken out to be analyzed (22). Alternatively the alveolar sampling can be made by means of an airtight, heated syringe set up on the expiratory end of the circuit (figure 2).

The $\mathrm{C}_{\mathrm{A}}$ and $\mathrm{C}_{\overline{\mathrm{E}}}$ measurements were made with the same gas chromatograph and mass selective detector

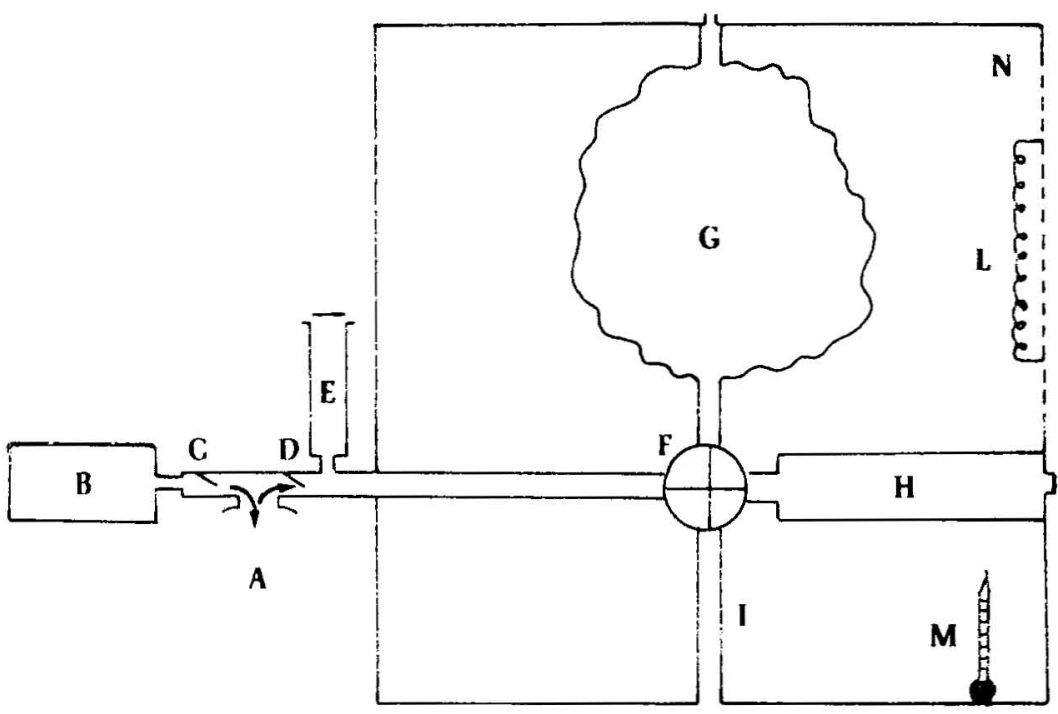

Figure 2. Apparatus employed to collect alveolar $\left(\mathrm{C}_{A}\right)$ and mixed-expired air samples $\left(C_{\hat{E}}\right)$ during exposure to styrene and to measure the pulmonary ventilation $(\dot{V}) .(A=$ mouthpiece, $B$ $=$ ultrasonic spirometer, $\mathrm{C}=$ inspiratory valve, $\mathrm{D}=\mathrm{ex}$ piratory valve, $E=$ gastight syringe to collect alveolar air samples, $F=$ fourway tap, $G=$ aluminum foil bag to collect mixed-expiratory air samples, $\mathrm{H}$ = alveolar air sampler, $\mathrm{I}=$ outside connection, $\mathrm{L}=$ electric resistance + thermostat, $M=$ thermometer, $\mathrm{N}=$ heated box) 
Table 1. Alveolar concentration: time-weighted environmental concentration $\left(\mathrm{C}_{\mathrm{A}}: \mathrm{C}_{i}\right)$ ratio throughout the experimental exposure (first, second, and third subgroups). The regression equation is the following: $C_{A}=0.12 \cdot C_{i}+16.2$ (correlation coefficient $=0.85$ ) (with $\mathrm{C}_{\mathrm{A}}$ and $\mathrm{C}_{\mathrm{i}}$ given in micromoles per liter).

\begin{tabular}{|c|c|c|c|c|c|c|c|c|c|c|c|c|c|c|c|}
\hline \multirow{2}{*}{ Subgroups } & \multirow{2}{*}{$\begin{array}{l}\text { Number } \\
\text { of cases }\end{array}$} & \multicolumn{2}{|c|}{$5 \mathrm{~min}$} & \multicolumn{2}{|c|}{$30 \mathrm{~min}$} & \multicolumn{2}{|c|}{$60 \mathrm{~min}$} & \multicolumn{2}{|c|}{$90 \mathrm{~min}$} & \multicolumn{2}{|c|}{$120 \mathrm{~min}$} & \multicolumn{2}{|c|}{$150 \mathrm{~min}$} & \multicolumn{2}{|c|}{$180 \mathrm{~min}$} \\
\hline & & ${ }_{\text {ratio }}^{\mathrm{C}_{\mathrm{A}}: \mathrm{C}_{\overline{\mathrm{I}}}}$ & SD & $\begin{array}{l}\mathrm{C}_{\mathrm{A}}: \mathrm{C}_{\overline{1}} \\
\text { ratio }\end{array}$ & SD & $\begin{array}{l}\mathrm{C}_{\mathrm{A}}: \mathrm{C}_{\mathrm{i}} \\
\text { ratio }\end{array}$ & SD & $\begin{array}{l}\mathrm{C}_{\mathrm{A}}: \mathrm{C}_{\mathrm{i}} \\
\text { ratio }\end{array}$ & SD & $\begin{array}{l}\mathrm{C}_{\mathrm{A}}: \mathrm{C}_{\mathrm{i}} \\
\text { ratio }\end{array}$ & $S D$ & $\begin{array}{l}\mathrm{C}_{\mathrm{A}}: \mathrm{C}_{\mathrm{i}} \\
\text { ratio }\end{array}$ & SD & $\begin{array}{l}\mathrm{C}_{\mathrm{A}}: \mathrm{C}_{\bar{I}} \\
\text { ratio }\end{array}$ & $\mathrm{SD}$ \\
\hline $\begin{array}{r}1^{\text {st }}+2^{\text {nd }}+3^{\text {rd }} \\
2^{\text {nd }}+3^{\text {rd }} \\
3^{\text {rd }}\end{array}$ & $\begin{array}{r}15 \\
10 \\
5\end{array}$ & 16.2 & 4.7 & 14.4 & 3.7 & 15.7 & 5.8 & 16.3 & 6.2 & 13.2 & 2.6 & 14.1 & 3.9 & 12.2 & 3.9 \\
\hline
\end{tabular}

Table 2. Single values of the time-weighted average of the environmental concentration ( $\left.\mathrm{C}_{\mathrm{i}}\right)$, the urinary concentration $\left(\mathrm{C}_{\mathrm{i}}\right)$, (urine sampled immediately after exposure), the venous blood concentration $\left(C_{v}\right)$ (blood withdrawn immediately before the end of exposure), and the uptake of styrene (U) during exposure. The last column shows the regression equation relating $C_{\tilde{u}}$ and $C_{j}$.

\begin{tabular}{|c|c|c|c|c|c|}
\hline Subgroup & $\underset{\left(\mu \mathrm{mol} / \mathrm{m}^{3}\right)}{\mathrm{C}_{\mathrm{i}}}$ & $\underset{\text { (nmol/l) }}{\mathrm{C}_{\overline{\mathrm{u}}}}$ & $\underset{\text { (nmol/I) }}{\mathrm{C}_{\mathrm{v}}}$ & $\underset{(\mu \mathrm{mol} / \text { time })}{\mathrm{U}}$ & Regression equation \\
\hline \multicolumn{6}{|l|}{ First } \\
\hline & $\begin{array}{l}516 \\
273\end{array}$ & $\begin{array}{l}69 \\
43\end{array}$ & $\begin{array}{l}713 \\
448\end{array}$ & $\begin{array}{r}187 \\
75\end{array}$ & $c_{i}=0.11 \cdot c_{i}+15.2$ \\
\hline$\overline{3}$ & 1035 & 149 & 1441 & 340 & $(r=0.97)$ \\
\hline 4 & 1375 & 157 & 1790 & 265 & \\
\hline 5 & 1037 & 128 & 1787 & 203 & \\
\hline \multicolumn{6}{|l|}{ Second } \\
\hline $\begin{array}{l}6 \\
7\end{array}$ & $\begin{array}{l}662 \\
388\end{array}$ & $\begin{array}{l}76 \\
64\end{array}$ & $\begin{array}{l}904 \\
842\end{array}$ & $\begin{array}{l}345 \\
286\end{array}$ & $\mathrm{C}_{\mathrm{u}}=0.16 \cdot \mathrm{C}_{\mathrm{i}}-2.6$ \\
\hline 8 & 917 & 202 & 2289 & 319 & $(r=0.93)$ \\
\hline 9 & 1654 & 251 & 3225 & 974 & \\
\hline 10 & 383 & 48 & 609 & 119 & \\
\hline \multicolumn{6}{|l|}{ Third } \\
\hline 11 & 281 & 45 & 401 & 193 & $C_{\tilde{u}}=0.17 \cdot C_{\bar{I}}+20.4$ \\
\hline 12 & 526 & 106 & 1095 & 206 & \\
\hline 13 & 535 & 115 & 1156 & 336 & $(r=0.95)$ \\
\hline 14 & 916 & 212 & 2005 & 496 & \\
\hline 15 & 1495 & 247 & 3045 & 943 & \\
\hline \multicolumn{6}{|l|}{ Fourth } \\
\hline 16 & 758 & 188 & 2601 & 935 & $C_{i}=0.26 \cdot C_{i}+21.7$ \\
\hline 17 & 547 & 167 & 2194 & 666 & \\
\hline 18 & 1096 & 297 & 3210 & 1427 & $(r=0.95)$ \\
\hline 19 & 1105 & 350 & 4381 & 1401 & \\
\hline 20 & 343 & 129 & 1543 & 356 & \\
\hline
\end{tabular}

and under the same analytical conditions used for the urine samples.

\section{Time-weighted average of the environmental} concentration measurement in the breathing zone

The activated charcoal of passive dosimeters, used in stage 2 only, were deabsorbed with $5 \mathrm{ml}$ of carbon disulfide and then kept at room temperature $\left(20^{\circ} \mathrm{C}\right)$ for $1 \mathrm{~h}$ and shaken periodically. Finally $0.5 \mu \mathrm{l}$ of the deabsorption liquid was injected into the gas chromatograph-mass selective detector unit.

\section{Results}

\section{Stage 1}

The average concentration in the exposure chamber $\left(C_{\bar{I}}\right)$ ranged from 273 to $1654 \mu \mathrm{mol} / \mathrm{m}^{3}$ [the conversion factor from milligrams to micromoles: $1 \mathrm{mg}=$ $9.6 \mu \mathrm{mol}$ (of styrene)] for the various subjects. During the exposure the chosen values for each subject were maintained at a relatively constant level (SD 23 $\mu \mathrm{mol} / \mathrm{m}^{3}$ ).
The alveolar concentration value $\left(C_{A}\right)$ was also found to be consistent for all the subjects up to the third exposure hour with a $C_{A}: C_{\bar{I}}$ ratio close to 0.15 (table 1).

The relative uptake $(R)$ (measured from $C_{\bar{I}}$ and $C_{\bar{E}}$ ) [R $=1-\left(\mathrm{C}_{\overline{\mathrm{E}}} / \mathrm{C}_{\overline{\mathrm{I}}}\right)$ ] was 0.68 [coefficient of variation (CV) $\pm 2.9 \%]$ in the subjects of the first three subgroups (at rest). In the subjects of subgroup 4 (for which no $C_{\breve{E}}$ measurements were made), the relative uptake was determined from the $C_{A}: C_{I}$ ratio values $\left[\mathrm{R}=-0.86 \cdot \mathrm{C}_{\mathrm{A}}: \mathrm{C}_{\overline{\mathrm{I}}}+79.3(9]\right.$, it was $0.64(\mathrm{CV} \pm$ $2.5 \%$ ).

The mean pulmonary ventilation (V) [under standard conditions $\left(0^{\circ} \mathrm{C}, 101.3 \mathrm{kPa}\right.$, dry)] was $6.3 \mathrm{l} / \mathrm{m}$ $(\mathrm{CV} \pm 13 \%)$ in the subjects at rest and $14.8 \mathrm{l} / \mathrm{m}(\mathrm{CV}$ $\pm 21 \%$ ) in the subjects of subgroup 4 .

Alveolar clearance $\left(\mathrm{Cl}_{\mathrm{A}}\right)$ [under standard conditions $\left(0^{\circ} \mathrm{C}, 101.3 \mathrm{kPa}\right.$, dry)] for styrene, where $\mathrm{Cl}_{\mathrm{A}}=\dot{\mathrm{V}}$. $\mathrm{R}$, was found to be $4.2 \mathrm{l} / \mathrm{m}$ (in the first three subgroups) and $9.4 \mathrm{l} / \mathrm{m}$ (in subgroup 4$)(\mathrm{CV} \pm 7.1$ and $\pm 21 \%$, respectively).

The amounts absorbed (total uptake) during the exposure time ranged from 75 to $1427 \mu \mathrm{mol}$ (table 2). 
The TWA environmental concentrations $\left(C_{\overline{1}}\right)$ and the urinary $\left(C_{\vec{u}}\right)$ and blood $\left(C_{v}\right)$ concentrations obtained for the 20 subjects at the end of exposure are shown in table 2, together with the uptake (U) and exposure time. The $\mathrm{C}_{\mathrm{u}}$ values displayed a statistically significant linear relationship to the corresponding $\mathrm{C}_{\mathrm{I}}$ (or $\mathrm{U}$ ), and the $\mathrm{C}_{\mathrm{A}}$ or $\mathrm{C}_{\mathrm{v}}$ values were also statistically significant:

$\mathrm{C}_{\mathrm{A}}=0.12 \cdot \mathrm{C}_{\mathrm{I}}+16.20$

(correlation coefficient 0.85$)(\mathrm{N}=85)$,

$\mathrm{C}_{\mathrm{v}}=2.9 \cdot \mathrm{U}+431$

(correlation coefficient 0.86$)(\mathrm{N}=15)$, and

$\mathrm{C}_{\overline{\mathrm{u}}}=0.23 \cdot \mathrm{U}+47.3$

(correlation coefficient 0.83$)(\mathrm{N}=15)$,

where $C_{A}$ and $C_{\bar{I}}$ are expressed in micromoles per cubic meter and $C_{\mathrm{v}}$ and $\mathrm{C}_{\overline{\mathrm{u}}}$ in nanomoles per liter and $\mathrm{U}$ in micromoles.

The mean alveolar concentration $\left(C_{A}\right)$ of the entire group of subjects was $112 \mu \mathrm{mol} / \mathrm{m}^{3}$. During the first $10 \mathrm{~min}$ following the end of the exposure the $\mathrm{C}_{\mathrm{A}}$ values at 30,150 , and $600 \mathrm{~s}$ were 19,16 , and 11 $\mu \mathrm{mol} / \mathrm{m}^{3}$, respectively, corresponding to a decrease of 83,86 , and $90 \%$ of the average end-exposure value $\left(108 \mu \mathrm{mol} / \mathrm{m}^{3}\right)$.

\section{Stage 2}

The same relationship between $C_{\bar{I}}$ and $C_{\bar{u}}$ observed experimentally also existed for the group of subjects occupationally exposed to styrene vapor (figure 3 ):

$\mathrm{C}_{\overline{\mathrm{u}}}=0.32 \cdot \mathrm{C}_{\overline{\mathrm{I}}}+154.2(\mathrm{~N}=101, \mathrm{r}=0.884)$,

where $C_{\overline{\mathrm{I}}}$ and $\mathrm{C}_{\overline{\mathrm{u}}}$ are expressed in micromoles per cubic meter and namomoles per liter, respectively.

\section{Discussion}

The starting values of the relative uptake $(\mathrm{R})$ and relative alveolar concentration $\left(C_{A}: C_{\bar{I}}\right)$ of styrene depend on their $\lambda$ blood : air ratios; our results $(R \simeq$ $0.66, C_{A}: C_{\bar{I}} \simeq 0.15$ ) are consistent with those of previous investigations $(1,3,10,15,37,38)$. The $R$ and $C_{A}: C_{\tilde{I}}$ curve (1) during exposure depends on the possibility of the biological tissues to store solvent and on the rate of its biotransformation; our results, in accordance with those already published $(1,13)$ show a practically constant curve for $R$ and $C_{A}: C_{\bar{I}}$ throughout the entire exposure time (therefore at least up to the end of the third hour) in the range of the environmental concentration values chosen $\left(273-1654 \mu \mathrm{mol} / \mathrm{m}^{3}\right.$ or $28.4-172.2 \mathrm{mg} / \mathrm{m}^{3}$ ).

The main aim of this report was, however, to determine if correlation relationships existed between styrene exposure standards $\left(\mathrm{C}_{\mathrm{I}}\right)$ and the concentration of styrene in samples of urine produced throughout the exposure time $\left(\mathrm{C}_{\mathrm{u}}\right)$.

Previous attempts at analyzing styrene as such in urine were unsuccessful due to the inaccuracy of the

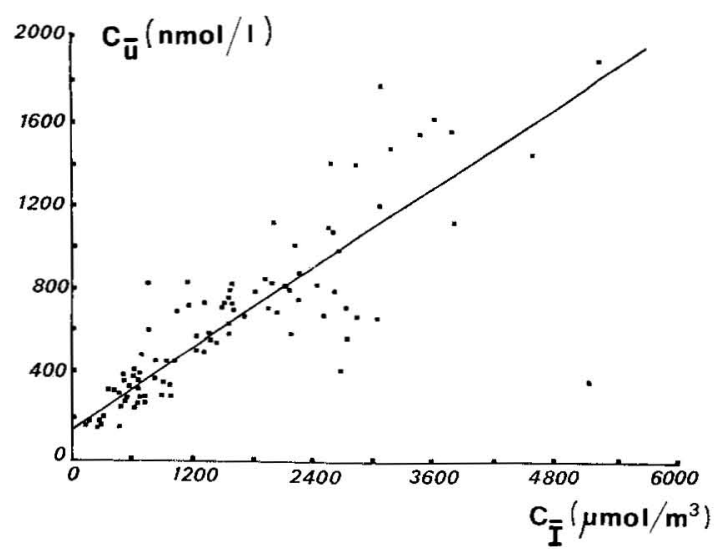

Figure 3. Scatter diagram relating the time-weighted average of the environmental concentration (in the breathing zone) $\left(\mathrm{C}_{i}\right)$ ( $x$ axis) and the urinary concentration $\left(\mathrm{C}_{\dot{u}}\right)$ (y axis) of styrene. The $C_{j}$ values ranged from 130 and $5156 \mu \mathrm{mol} / \mathrm{m}^{3}$ (median value $1138 \mu \mathrm{mol} / \mathrm{m}^{3}$; geometric standard deviation 2.23). The regression line is also drawn.

analytical procedures (3). Highly sensitive equipment is now available to solve the problem.

The slope of the regression lines was different in the four subgroups considered. It was lowest in subgroup 1 (1-h exposure at rest) (regression coefficient 0.11 ) and highest in subgroup 4 (2-h exposure spent partly at rest, partly performing light physical exercise of $50 \mathrm{~W}$ ) (regression coefficient 0.26 ); 2 and $3 \mathrm{~h}$ of exposure at rest were charaçterized by intermediate slopes (regression coefficients 0.16 and 0.17 , respectively) (figures 4 and 5).

The difference in the slope between the equations obtained after 1 and $2 \mathrm{~h}$ of exposure (0.11 against 0.16$)$ was significantly higher than that between 2 and $3 \mathrm{~h}$ of exposure (0.16 against 0.17 ). This occurrence was probably due to a continuous increase in styrene concentration in arterial blood from the beginning of exposure up to $1 \mathrm{~h}$ or more later $(6,10,37,38)$.

The urinary concentrations should be in fact proportional to those in the arterial blood, with a proportional coefficient corresponding to the $\lambda$ blood/ urine value, on the assumption that the exchange of the solvent between the arterial blood and urine occurs after simple partition in accordance with Henry's law.

In this case, once a constant arterial concentration value has been reached, the slope of the regression lines should be independent of exposure time. The small slope difference of the regression lines corresponding to 2 and $3 \mathrm{~h}$ of exposure (figure 5) should mean that an increment in the blood concentration is still occurring throughout the third hour of exposure or that a stable level of urinary concentration is not rapidly reached, a phenomenon similar to what happens to the alveolar (constant) and arterial concentration (increasing up to over $75 \mathrm{~min}$ of exposure) $(37,38)$.

The greatest slope of the regression line in subgroup 4 (regression coefficient 0.26 ) was due to the work 


$$
X=C_{\bar{I}}\left(\mu \mathrm{mol} / \mathrm{m}^{3}\right) \quad Y=C_{\bar{u}}(\mathrm{nmol} / \mathrm{l})
$$
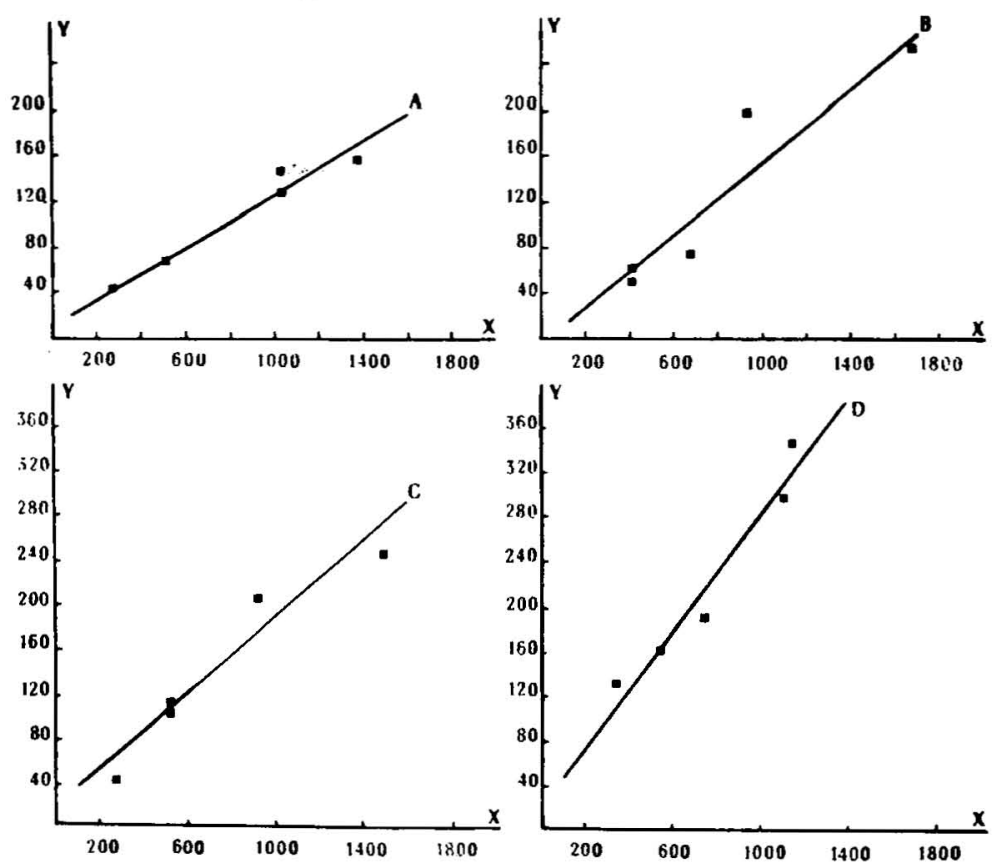

Figure 4. Regression lines drawn on scatter diagrams relating the timeweighted average of the environmental concentration (in the breathing zone) $\left(\mathrm{C}_{j}\right)[\mathrm{x}$ axis] and the urinary concentration $\left(C_{\dot{u}}\right)$ [y axis] of styrene (urine collected immediately after the exposure was over. $[\mathrm{A} \doteq$ subgroup $1(1-\mathrm{h}$ exposure, at rest); $B=$ subgroup $2(2-\mathrm{h}$ exposure, at rest); $C=$ subgroup $3(3-h$ exposure, at rest); $\mathrm{D}=$ subgroup $4(2-\mathrm{h}$ exposure during light physical exercise and alternately at rest] load. Under such conditions, $R$ values being equal, the amounts of styrene taken up are clearly larger (depending on pulmonary ventilation), and greater solvent concentrations are therefore reached in arterial blood (10), and consequently greater urinary concentrations as well.

The four regression lines start practically from the origin of the Cartesian coordinates (figure 5) (intercepts of the $y$ axis between -2.6 and $21.7 \mathrm{nmol} / \mathrm{l}$ ) because the subjects under study had never been exposed to styrene previously.

A close relationship between the TWA environmental concentration in the breathing zone $\left(\mathrm{C}_{i}\right)$ and the urinary concentration of styrene in urine samples collected after $4 \mathrm{~h}$ of exposure also existed for the group of occupationally exposed subjects (correlation coefficient 0.88 ), the regression coefficient being 0.32 .

The regression line does not start from the origin of the Cartesian coordinates but intercepts the $y$ axis at $154 \mathrm{nmol} / \mathrm{l}$ (figure 3 and 6); this finding indicates that at the beginning of the exposure period there was some styrene in the blood of the subjects under study, as expected and previously documented $(9,10)$.

The urinary concentration $\left(\mathrm{C}_{\mathrm{u}}\right)$ corresponding to the TLV-TWA $\left(2065 \mu \mathrm{mol} / \mathrm{m}^{3}\right)$ is $815 \mathrm{nmol} / \mathrm{l}$ (figure 6). To propose a biological exposure limit - based on $4 \mathrm{~h}$ of occupational exposure and on conditions of a light work load - it is necessary to consider the corresponding $95 \%$ lower confidence limit of the regression line (biological threshold $740 \mathrm{nmol} / \mathrm{l}$ ). To compare the single urinary concentration values with the chosen threshold (for a decision of compliance or non- compliance occupational exposure), ${ }^{3}$ it is advisable to consider the one-sided lower (LCL) and upper (UCL) confidence limits (at $95 \%$ ) [UCL $(95 \%)=\mathrm{C}_{\overline{\mathrm{u}}}+$ $1.645 \cdot \mathrm{CV}_{\mathrm{T}} \cdot \mathrm{TLV}, \mathrm{LCL}(95 \%)=\mathrm{C}_{\overline{\mathrm{u}}}-1.645 \cdot \mathrm{CV}_{\mathrm{T}}$ - $T L V$, where $C V_{T}$ is the coefficient of variation of the method and the factor 1.645 is the $95^{\text {th }}$ percentile of the standardized normal distribution] of each single determination of urinary concentration starting from the total coefficient of variation of the method (26) (figure 6).

The biological indicators presently proposed to evaluate the occupational exposure to styrene are $(1,2,5$, $11,18,19)$ : (i) the urinary concentration of mandelic and phenylglyoxylic acid, (ii) the styrene concentration in alveolar or mixed-expired air, and (iii) the styrene concentration of venous or arterial capillary blood. The proposed threshold values are $1 \mathrm{~g}(6.57 \mathrm{~mol}) / 1$ for mandelic acid and/or $250 \mathrm{mg}(1.66 \mathrm{~mol}) / \mathrm{l}$ for phenylglyoxylic acid in urine (where the urine was collected at the end of the workshift), $40 \mathrm{ppb}$ and $18 \mathrm{ppm}$ of styrene in mixed-expired air (before and during the workshift, respectively), and $0.02 \mathrm{mg} / \mathrm{l}$ and $0.55 \mathrm{mg} / 1$ for styrene in venous blood (before and during the workshift, respectively) (2).

The results obtained both experimentally in volunteers exposed in an exposure chamber and in groups

\footnotetext{
${ }^{3}$ Compliance exposure: $95 \%$ confidence based on measurements that a worker's exposure is below the standard; noncompliance exposure: $95 \%$ confidence that a worker's exposure is above the standard; possible overexposure: any exposure which cannot be classified as compliance or noncompliance exposure.
} 


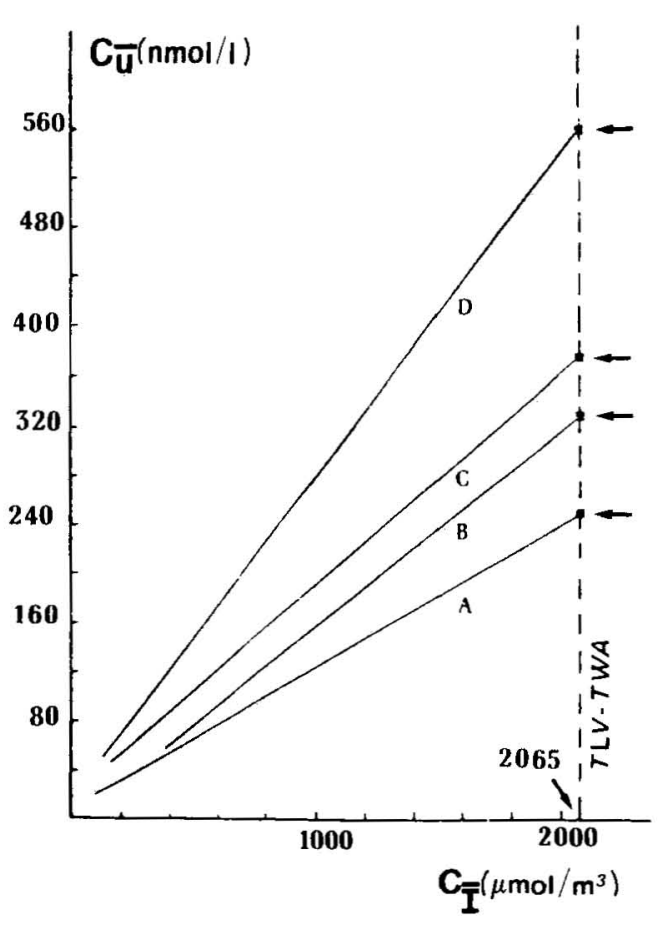

Figure 5. Regression lines relating the time-weighted average of the environmental concentration (in the breathing zone) $\left(\mathrm{C}_{i}\right)$ and the urinary concentration of styrene $\left(C_{i}\right)$; A B C D refer to the four subgroups considered. See figure 4 for an explanation of the groups. Arrows indicate the $C_{\dot{u}}$ extrapolated values at the time-weighted average of the threshold limit value for styrene $\left(2065 \mu \mathrm{mol} / \mathrm{m}^{3}=215 \mathrm{mg} / \mathrm{m}^{3}\right)\left(\mathrm{C}_{\tilde{u}}\right.$ biological exposure limit: $A=242 \mathrm{nmol} / \mathrm{l}, \mathrm{B}=328 \mathrm{nmol} / \mathrm{l}, \mathrm{C}=371 \mathrm{nmol} / \mathrm{l}, \mathrm{D}=$ $559 \mathrm{nmol} / \mathrm{ll})$

of subjects occupationally exposed enable us to include also the styrene urinary concentration in the already proposed biological exposure indice. With regard to the meaning and the value used to ascribe to the various biological indicators proposed, it should be pointed out that the blood $\left(\mathrm{C}_{\mathrm{v}}, \mathrm{C}_{\mathrm{a}}\right)$ and air $\left(\mathrm{C}_{\mathrm{A}}, \mathrm{C}_{\overline{\mathrm{E}}}\right)$ measurements are instantaneous values, while the unchanged urinary styrene $\left(\mathrm{C}_{\dot{u}}\right)$ and styrene urinary metabolites are weighted values. However they are not indicators of the same exposure time. In fact the metabolic indicator phase depends on the rate of biotransformation. Its metabolites can also be classified as effect indicators. On the contrary the unchanged styrene urinary elimination during exposure indicates a natural integration over time of the rather fast partition between air and arterial blood and between arterial blood and urine (the bladder serving as a collecting and mixing vessel).

Besides, the situations of highest uptake of styrene (environmental concentration being equal) by subjects working under different work loads are clearly indicated by the urinary concentration values. On the contrary it is well known that, mainly with highly soluble solvents (like styrene), increases in pulmonary ventilation do not bring about proportional increases in alveolar concentration $(1,37)$. Thus $C_{A}$ values correlate

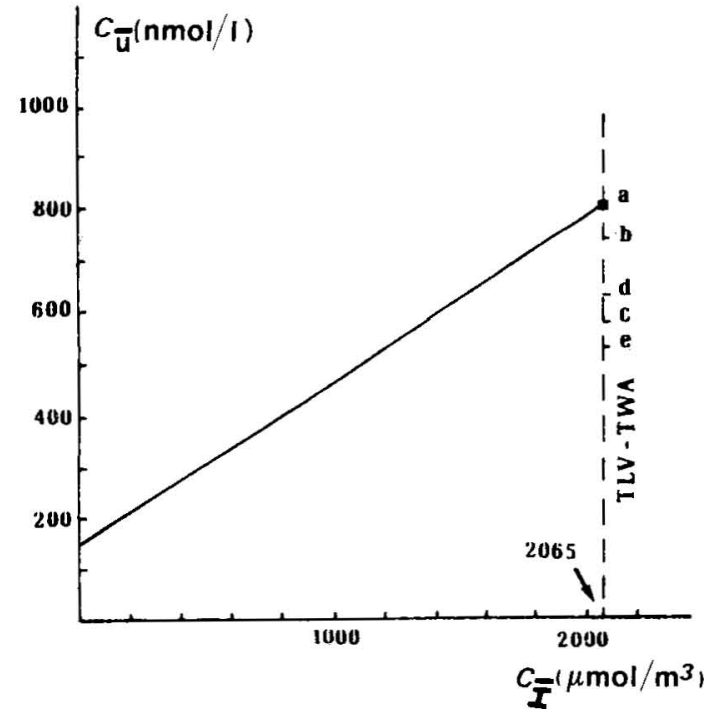

Figure 6. Regression line relating the time-weighted average (TWA) of the environmental concentration (in the breathing zone) $\left(\mathrm{C}_{i j}\right)$ and the urinary concentration of styrene $\left(\mathrm{C}_{\dot{u}}\right)$ for occupationally exposed subjects (urine collected every $4 \mathrm{~h}$ of exposure); the corresponding regression equation is the following: $\mathrm{C}_{\dot{j}}=0.32 \cdot \mathrm{C}_{i}+154.2$ (correlation coefficient $=0.88$; $N=101$ ). [TLV: threshold limit value; $a: C_{\dot{u}}$ value at $C_{i}=2065$ $\mu \mathrm{mol} / \mathrm{m}^{3}$ (TLV-TWA); b: $95 \%$ lower confidence limit = biological exposure limit; $c$ : hypothetical value of $\mathrm{C}_{\dot{u}}$ in an occupationally exposed subject; $d$ : one-sided upper confidence limit (at $95 \%$ ) of $\mathrm{C}_{\mathrm{i}}$; e: one-sided lower confidence limit (at $95 \%$ ) of $C_{i}$; classification system: (i) $d<b$ (or $d / b<1$ ) $=$ compliance exposure, (ii) $e>b$ (or $e / b>1)=$ noncompliance ex. posure, and (iii) any individual who cannot be classified in $i$ or $\mathrm{ii}=$ possible overexposure]

well with $C_{\bar{I}}$ values (5) but not with the amounts of styrene taken up.

Finally it is to be pointed out that the unchanged styrene urinary concentration should not be affected either by other solvents interfering with each other in the biotransformation rate or by the presence of common metabolites (38). Last, the method is simple, quickly performed, and noninvasive.

The exchange of styrene between renal arterial blood and urine could occur (similar to what is believed to take place at the alveolocapillary level) by means of a simple partition mechanism between these two fluids regulated by the $\lambda$ blood/urine value; in this case a pressure equilibrium should be reached with $\mathrm{P}_{\mathrm{A}}=\mathrm{P}_{\mathrm{a}}$ $=\mathrm{P}_{\mathrm{u}}(20)$ (and then $\mathrm{C}_{\mathrm{a}} / \mathrm{C}_{\mathrm{A}}=\lambda$ blood/air; $\mathrm{C}_{\mathrm{a}} / \mathrm{C}_{\mathrm{u}}=$ $\lambda$ blood/urine). Such a hypothesis has already been advanced (existence of an alveolourinary inert gas partial pressure equilibrium) and employed in the field of pulmonary physiology $(4,24,30)$.

The mean value of $\mathrm{C}_{\overline{\mathrm{u}}}$ in the group of subjects exposed for $3 \mathrm{~h}$ at rest (subgroup 3) was $145 \mathrm{nmol} / \mathrm{l}$, and the mean value of $\mathrm{C}_{\mathrm{A}}$ in the same group was 103 $\mu \mathrm{mol} / \mathrm{m}^{3}$.

The experimental value of the $\mathrm{C}_{\mathrm{a}}: \mathrm{C}_{\mathrm{A}}$ ratio corresponded to the in vitro $\lambda$ blood/urine value (37). Therefore the styrene arterial concentration $\left(C_{a}\right)$ (at 
equilibrium) is likely to be about $\mathrm{C}_{\mathrm{A}} \cdot \lambda$, ie, in this case, $5350 \mathrm{nmol} / 1$. [No direct measurement of the styrene concentration in arterial blood was made because the introduction of a catheter into an artery was not included in the acceptance protocol of the volunteers and because reference data are already available $(1,12,37,38)$.]

On the assumption that the $\mathrm{C}_{\mathrm{a}}: \mathrm{C}_{\mathrm{A}}$ ratio corresponds to the in vitro $\lambda$ blood/urine value $(\lambda=7.29)$ (17), ihe value of $C_{\bar{u}}$ in the last parts of the urine, filtered towards the third hour of exposure, should be $735 \mathrm{nmol} / \mathrm{l}$; the time-weighted value of $\mathrm{C}_{\overline{\mathrm{u}}}$, of the entire urine sample filtered throughout the $3 \mathrm{~h}$ of exposure, was $145 \mathrm{nmol} / \mathrm{l}$. Such a value is not in contrast with the hypothesis advanced. Moreover none of the $\mathrm{C}_{\overline{\mathrm{u}}}$ values suggested an active mechanism of renal styrene elimination.

In conclusion, analogous to what has been observed for other substances [n-hexane (23), toluene (29), pdichlorobenzene (17), methyl ethyl ketone (27), nitrous oxide $(34,35)$, and methanol $(14,33)]$, we believe that also for styrene the measurement of urinary concentration is a useful biological indicator of exposure.

\section{References}

1. Åstrand I, Kilbom A, Övrum P, Wahlberg I, Vesterberg D. Exposure to styrene: I Concentration in alveolar air and blood at rest and during exercise and metabolism. Work Environ Health 11 (1974) 69-85.

2. American Conference of Governmental Industrial Hygienists. Exposure indices proposed by ACGIH for 1984-85. Cincinnati, OH 1984, p 62.

3. Bardoney Z. Styrene metabolism. Cesk Hyg 9 (1964) $223-239$. Cited by the National Institute for Occupational Safety and Health. Occupational exposure to styrene (criteria for a recommended standard). Cincinnati, OH 1983. (DHHS 83-119).

4. Briscoe WA, Gurtner HP. The alveolo-urinary $\mathrm{N}_{2}$ partial pressure difference compared to other measures of the distribution of ventilation and perfusion within the lung. Fed Proc 9 (1960) 381.

5. Brugnone F, Perbellini L, Gaffuri E, Apostoli P. Biomonitoring of industrial solvent exposures in workers' alveolar air. Int Arch Occup Environ Health 47 (1980) 245-261.

6. Carlsson A. Distribution and elimination of ${ }^{14} \mathrm{C}$-styrene in rat. Scand J Work Environ Health 7 (1981) 45-50.

7. Dolara P, Caderni G, Lodovici M, Santoni G, Salvadori M, Baroni A. Determination of styrene in the urine of workers manufacturing polystyrene plastics. Ann Occup Hyg 28 (1984) 195-199.

8. Dutkiewicz T, Tyras H. Skin absorption of toluene, styrene and xylene in man. Br J Ind Med 25 (1968) 243.

9. Engström J, Astrand I, Wigaeus E. Exposure to styrene in a polimerization plant. Scand J Work Environ Health 4 (1978) 324-329.

10. Engström J, Bjurström R, Ảstrand I, Övrum P. Uptake, distribution and elimination of styrene in man: Concentration in adipose tissue. Scand J Work Environ Health 4 (1978) 315-323.

11. Engström K, Härkönen $H$, Kalliokoski $P$, Rantanen J. Urinary mandelic acid concentration after occupational exposure to styrene and its use as a biological exposure test. Scand J Work Environ Health 2 (1976) 21-26.
12. Engström K, Härkönen H, Pekari K, Rantanen J. Evaluation of occupational styrene exposure by ambient air and urine analysis. Scand J Work Environ Health 4 (1978): suppl 2, 121-123.

13. Fernandez JG, Caperos JR. Exposition au stirène: I Etude de l'absorption et de l'excrétion pulmonaires sur des sujets humains. Int Arch Occup Environ Health $\mathbf{4 0}$ (1977) $1-12$.

14. Ferry DG, Temple WA, McQueen EG. Methanol monitoring. Int Arch Occup Environ Health 47 (1980) $155-163$.

15. Fiserova-Bergerova V, Teisinger J. Pulmonary styrene vapor retention. Ind Med Surg 34 (1965) 620.

16. Ghittori S, Imbriani M, Pezzagno G. Un sistema aperto per esposizioni a concentrationi note e controllate di aeriformi. G Ital Med Lav 5 (1983) 251-254.

17. Ghittori S, Imbriani M, Pezzagno G. Esperienze sugli equilibri fra comparto ambientale e compartimenti biologici. In: "Esposi zioni occupazionale a solventi: Stato attuale, prospettive e limiti del monitoraggio" PAVIA - Maggio 1984 La Goliardica Pavese. 1984, pp 193-226.

18. Götell $P$, Axelson $O$, Lindelof $B$. Field studies on human styrene exposure. Work Environ Health 9 (1972) 76-83.

19. Hake CL, Stewart RD, Wu A, Graff SA, Forster HV, Keeler WH, Lebrun AJ, Newton PB, Soto RJ. Styrene - Development of a biological standard for the industrial worker by breath analysis. National Institute for Occupational Safety and Health, Cincinnati, OH 1977, p 141. (HEW publication).

20. Hatch TF, Cook KM. Partial respirometry: A system for measuring pulmonary functional capacity in terms of its elements: Ventilation, diffusion, blood flow. Arch Ind Health 11 (1955) 142-158.

21. Ikeda M, Imamura T, Hayashi M, Tabuchi T, Hara I. Evaluation of hippuric, phenylglyoxylic and mandelic acids in urine as indices of styrene exposure. Int Arch Arbeitsmed 32 (1974) 93-101.

22. Imbriani M, Ghittori S, Pezzagno G. Valutazione di un nuovo campionatore di aria alveolare. G Ital Med Lav 4 (1982) $271-278$.

23. Imbriani M, Ghittori S, Pezzagno G, Capodaglio E. nHexane urine elimination and weighted exposure concentration. Int Arch Occup Environ Health 55 (1984) $33-41$.

24. Klocke FJ, Rahn H. The arterial-alveolar inert gas difference in normal and emphysematous subjects, as indicated by the analysis of urine. J Clin Invest 40 (1961) $286-294$.

25. Lauterberger WJ, Kring CV, Morello JA. Theory of passive monitors. In: Kelley WD, ed. Dosimetry for chemical and physical agents. American Conference of Governmental Industrial Hygienists, Cincinnati, $\mathrm{OH}$ 1981, pp 91-99.

26. Leidel NA, Busch KA, Lynch JR. Occupational exposure: Sampling strategy manual. National Institute for Occupational Safety and Health, Cincinnati, $\mathrm{OH} 1977$, pp $47-69$.

27. Miyasaka M, Kumai M, Koizumi A, Watanabe T, Kurasako $\mathrm{K}$, Sato $\mathrm{K}$, Iheda $\mathrm{M}$. Biological monitoring of occupational exposure to methyl ethyl ketone by means of urinalysis for methyl ethyl ketone itself. Int Arch Occup Environ Health 50 (1982) 131-137.

28. National Institute for Occupational Safety and Health. Occupational exposure to styrene (criteria for a recommended standard). Cincinnati, OH 1983. (DHHS 83-119).

29. Pezzagno G, Imbriani M, Ghittori S, Capodaglio E. Il significato della eliminazione urinaria di toluolo come indicatore di esposizione. Med Lav 76 (1985): 1, 44-60.

30. Rahn $\mathrm{H}$, Klocke FJ. The $\mathrm{N}_{2}$ gas tension difference between urine and alveolar gas. Fed Proc 18 (1959) 124.

31. Riihimäki V, Pfaffli P. Percutaneous absorption of sol- 
vent vapors in man. Scand $\mathrm{J}$ Work Environ Health 4 (1978) $73-85$.

32. Sato A, Nakajima T. Partition coefficients of some aromatic hydrocarbons and ketones in water, blood and oil. Br J Ind Med 36 (1979) 231-234.

33. Sedivec V, Mraz M, Flek J. Biological monitoring of persons exposed to methanol vapours. Int Arch Occup Environ Health 48 (1981) 257-279.

34. Sonander $M$, Sterquist $\mathrm{O}$, Nilsson $\mathrm{K}$. Urinary $\mathrm{N}_{2} \mathrm{O}$ as a measure of biological exposure to nitrous oxide anaesthetic contamination. Ann Occup Hyg 27 (1983) $73-79$.

35. Sonander M, Sterquist $O$, Nilsson $K$. Exposure to trace amounts of nitrous oxide. Br J Anaesth 55 (1983) $1225-1229$.
36. Stewart RD, Dodd HC, Baretta BD, Shaffer AW. Human exposure to styrene vapor. Arch Environ Health 16 (1968) 656-662.

37. Wigaeus E, Lof A, Bjurstrom R, Byfalt Nordqvist $\mathbf{M}$. Exposure to styrene - Uptake, distribution metabolism and elimination in man. Scand $\mathbf{J}$ Work Environ Health 9 (1983) 479-488.

38. Wigaeus E, Lof A, Byfalt Nordqvist M. Uptake, distribution, metabolism and elimination of styrene in man: A comparison between single exposure and co-exposure with acetone. $\mathrm{Br} \mathrm{J}$ Ind Med 41 (1984) 539-546.

Received for publication: 25 February 1985 